\title{
Hot topic: Selecting cattle for low residual feed intake did not affect daily methane production but increased methane yield
}

\author{
H. E. Flay, ${ }^{1}$ B. Kuhn-Sherlock, ${ }^{1}$ K. A. Macdonald, ${ }^{1}$ M. Camara, ${ }^{1}$ N. Lopez-Villalobos, ${ }^{2}$ D. J. Donaghy, ${ }^{2}$ \\ and J. R. Roche ${ }^{1,3 *}$ \\ ${ }^{1}$ DairyNZ Limited, Newstead, Private Bag 3221, Hamilton 3210, New Zealand \\ ${ }^{2}$ School of Agriculture and Environment, Massey University, Palmerston North 4410, New Zealand \\ ${ }^{3}$ School of Biological Sciences, University of Auckland, Private Bag 92019, Auckland 1142, New Zealand
}

\section{ABSTRACT}

Reducing enteric methane $\left(\mathrm{CH}_{4}\right)$ production and improving feed conversion efficiency of dairy cows is of high importance. Residual feed intake (RFI) is one measure of feed efficiency, with low RFI animals being more efficient in feed conversion. Enteric $\mathrm{CH}_{4}$ is an important source of digestible energy loss in ruminants and, because research in beef cattle has reported a positive relationship between RFI and daily $\mathrm{CH}_{4}$ production, we hypothesized that low RFI dairy heifers, which are more feed efficient, would produce less $\mathrm{CH}_{4} / \mathrm{d}$. We measured the daily methane production $\left(\mathrm{g}\right.$ of $\mathrm{CH}_{4} / \mathrm{d}$ ), methane yield [g of $\mathrm{CH}_{4} / \mathrm{kg}$ of dry matter intake (DMI)], and $\mathrm{CH}_{4}$ per kilogram of body weight (BW) gain for 56 heifers $(20-22 \mathrm{mo}$ old $)$ in a $2 \times 2$ factorial arrangement: factors included 2 breeds (Holstein-Friesian and Jersey; $\mathrm{n}=28 /$ breed), with equal numbers of animals previously determined as being either high $[+2.0 \mathrm{~kg}$ of dry matter $(\mathrm{DM}) / \mathrm{d}$ ] or low RFI $(-2.1 \mathrm{~kg}$ of $\mathrm{DM} / \mathrm{d} ; \mathrm{n}$ $=28 /$ RFI category). All heifers were commingled and offered unrestricted access to the same diet of dried alfalfa cubes. Between RFI categories, heifers did not differ in BW or BW gain but low RFI heifers had 9.3 and $10.6 \%$ lower DMI and DMI $/ \mathrm{kg}$ of BW, respectively, than high RFI heifers. Similarly, RFI category did not affect $\mathrm{CH}_{4} / \mathrm{d}$ or $\mathrm{CH}_{4} / \mathrm{kg}$ of $\mathrm{BWg}$, but $\mathrm{CH}_{4} / \mathrm{kg}$ of DMI was higher in low RFI heifers because of their lower DMI. These results might reflect more complete digestion of ingested feed in the more efficient, low RFI heifers, consistent with previous reports of greater apparent digestibility of organic matter. Holstein-Friesian heifers were heavier and consumed more total DM than Jersey heifers, but breed did not affect DMI $/ \mathrm{kg}$ of BW or BWg. Jersey heifers produced less $\mathrm{CH}_{4} / \mathrm{d}$, but not $\mathrm{CH}_{4} / \mathrm{kg}$ of DMI or $\mathrm{CH}_{4} / \mathrm{kg}$ of BWg. We detected no interaction between breed and RFI category in any of the

Received June 18, 2018.

Accepted November 2, 2018.

*Corresponding author: john.roche@mpi.govt.nz variables measured. In conclusion, differences in RFI in dairy heifers did not affect daily $\mathrm{CH}_{4}$ production $(\mathrm{g} / \mathrm{d})$; however, low RFI heifers had a greater $\mathrm{CH}_{4}$ yield $(\mathrm{g} / \mathrm{kg}$ of DMI) on a high forage diet.

Key words: feed conversion efficiency, environmental sustainability, greenhouse gas

\section{Hot Topic}

Rapid growth in the global human population and concomitant rising demand for animal products are generating concerns that enteric methane $\left(\mathrm{CH}_{4}\right)$ emissions are contributing to climate change (Garnsworthy et al., 2012; Ramin and Huhtanen, 2013; Huhtanen et al., 2015). Agriculture and land use change is estimated to contribute 14 to $22 \%$ of global greenhouse gas emissions, and $\mathrm{CH}_{4}$ from production ruminants is reported to be almost $6 \%$ of total greenhouse gases (Knapp et al., 2014). Therefore, considerable interest exists in genetic or management-level strategies to reduce this source of greenhouse gas.

Improving feed conversion efficiency (FCE) could help reduce these emissions while maintaining current levels of production (Waghorn et al., 2012; Potts et al., 2015). Ruminants eruct 5 to $10 \%$ of their gross energy intake as $\mathrm{CH}_{4}$ (van Soest, 1994; Pacheco et al., 2014). If variability in $\mathrm{CH}_{4}$ emissions is a component of differences in feed efficiency, selective breeding for more feed-efficient animals could both reduce $\mathrm{CH}_{4}$ emissions and increase productivity.

Residual feed intake (RFI) is a measure of FCE that describes the difference between an animal's predicted DMI and actual DMI required for its maintenance and production. Residual feed intake has been positively associated with daily $\mathrm{CH}_{4}$ production in beef steers (Nkrumah et al., 2006; Hegarty et al., 2007; Fitzsimons et al., 2013), and between-animal differences in RFI have been reported within dairy cow breeds (Pryce et al., 2012; Davis et al., 2014; Macdonald et al., 2014). Furthermore, differences in FCE have been reported within and between breeds, with Jersey $(\mathbf{J})$ cows re- 
quiring less feed than Holstein-Friesian (HF) cows per kilogram of milk components produced (L'Huillier et al., 1988; Prendiville et al., 2009; Spaans et al., 2018). This is probably due to the larger gastrointestinal tract per unit BW of J cows compared with HF cows, thus promoting an increase in NDF and DM digestibility (Beecher et al., 2014). It is, therefore, plausible that dairy breeds differ in daily $\mathrm{CH}_{4}$ production and yield per unit intake, although a review of the available literature does not support this (Goddard and Grainger, 2003).

We hypothesized that highly feed efficient (low RFI) animals would emit less $\mathrm{CH}_{4} / \mathrm{kg}$ of DMI than lower efficiency (high RFI) animals, and that J heifers would have lower $\mathrm{CH}_{4} / \mathrm{kg}$ of DMI than HF heifers. To test our 2 hypotheses, we measured daily $\mathrm{CH}_{4}$ production (g of $\mathrm{CH}_{4} / \mathrm{d}$ ) in a $2 \times 2$ factorial arrangement of breed and predefined RFI category: $28 \mathrm{HF}$ and $28 \mathrm{~J}$ heifers (20-22 mo old) identified during the 2 mo before this experiment as being either high or low for RFI (i.e., $\mathrm{n}=$ 14 HF-high, 14 HF-low, 14 J-high, and 14 J-low).

The experiment was undertaken at Lye Farm, Hamilton, New Zealand $\left(37.78^{\circ} \mathrm{S}, 175.28^{\circ} \mathrm{E}\right)$ between March and June 2017. The Ruakura Animal Ethics Committee (Hamilton, New Zealand) approved all animal manipulations in accordance with the New Zealand Animal Welfare Act (1999). The experiment was appropriately powered to detect a $5 \%$ difference in methane yield $\left(\mathrm{CH}_{4} / \mathrm{kg}\right.$ of DMI) between treatments. The experiment was not adequately powered to measure the interaction between the main effects; therefore, we present only the main effects.

We selected 56 dairy heifers, 20 to 22 mo old, from an experiment designed to measure the RFI of HF and J heifers. Briefly, we procured 280 heifers $(140 \mathrm{HF}$ and $140 \mathrm{~J})$, representing 30 elite sires $(\mathrm{n}=5$ to 10 heifers per sire), on loan from commercial dairy farms across the North Island of New Zealand and transported them to the Dairy Trust Taranaki (Hawera, Taranaki, New Zealand $39.59^{\circ} \mathrm{S}, 174.28^{\circ} \mathrm{E}$ ) research facility to measure RFI. The Hawera research facility was described in detail by Waghorn et al. (2012). Briefly, the facility contained twenty-eight $42-\mathrm{m}^{2}$ pens bedded with coarse wood shavings on top of stones and drainage pipes. Each pen contained a single feeding station, accessible to one animal at a time, with the feed bin mounted on load cells. Bin weight and animal identification (ID) were recorded continuously when an animal accessed feed; intake, time, and duration of eating were recorded. Access to the feed was via a narrow chute and individual ID was recorded by an electronic ID (EID) reader (Gallagher G03103 R series; Gallagher Group Ltd., Hamilton, New Zealand) mounted above the feed bin. Four load cells supported each bin, and weights were recorded at 0.02 -s intervals to an accuracy of 0.1 $\mathrm{kg}$. Water was freely available.

We divided the 280 heifers into 2 cohorts ( $\mathrm{n}=140$ / cohort), with equal representation of $\mathrm{HF}$ and $\mathrm{J}$ in each cohort, and offered unrestricted access to dried alfalfa cubes (Medicago sativa; supplied by MultiCube Stockfeeds Ltd., Yarrawonga, Australia). We measured heifer intake over a 52-d period and assessed BW 3 times a week. At the end of each cohort's measurement period, individual heifer RFI was calculated by regressing DMI against metabolic BW $\left(\mathrm{BW}^{0.75}\right)$ and $\mathrm{BW}$ gain $(\mathbf{B W g})$, and the top $10 \%(+2.0 \mathrm{~kg}$ of $\mathrm{DM} / \mathrm{d})$ and bottom $10 \%$ $(-2.1 \mathrm{~kg}$ of DM/d) for RFI within each breed and cohort were selected for assessment of $\mathrm{CH}_{4}$ production ( $\mathrm{n}=7$ heifers per breed and RFI category within each cohort group; see Figure 1).

Immediately following assessment for RFI, selected heifers were transported to DairyNZ Lye Farm, Hamilton, New Zealand ( $\mathrm{n}=14$ heifers/breed per cohort) and housed in the DairyNZ $\mathrm{CH}_{4}$ measurement facility. The $\mathrm{CH}_{4}$ measurement facility consisted of a freestall barn with 30 raised cubicle sand beds. The barn was split into 2 halves with 15 stalls per pen. Seven feed stations with similar dimensions to the feed bins described previously were installed, with 3 feed stations in one pen and 4 in the other pen. These feed stations identified animals automatically via an EID reader placed on top of the feed bin and recorded feed disappearance and $\mathrm{CH}_{4}$ production as the animal ate. Zimmerman et al. (2015) provided a complete description of the feed-

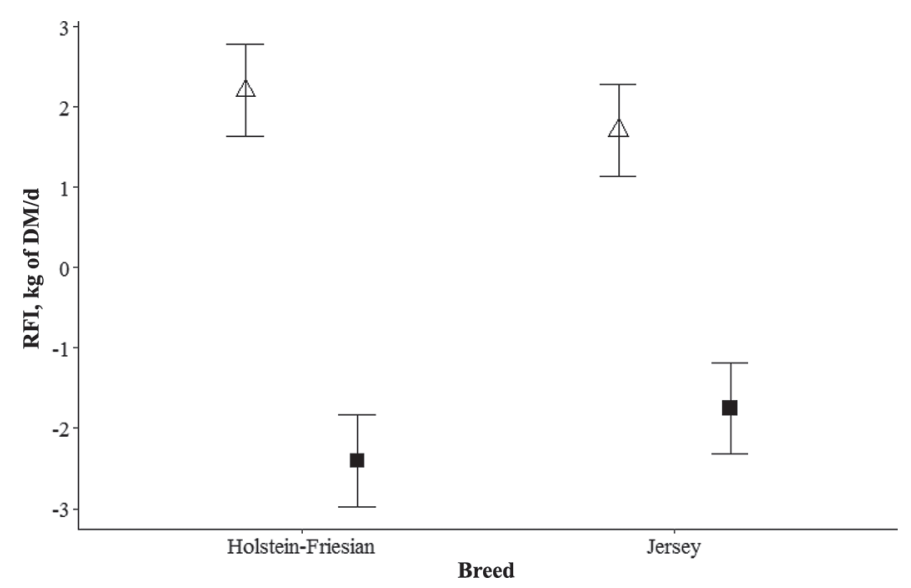

Figure 1. Residual feed intake (RFI) of 4 groups of dairy heifers representing 2 breeds (Holstein-Friesian and Jersey) and 2 previously determined RFI categories (high: $+2.0 \mathrm{~kg}$ of DM, $\Delta$; low: $-2.1 \mathrm{~kg}$ of DM, $)$. Heifers were 20 to 22 mo old; BW $=480$ and $408 \mathrm{~kg}$ for Holstein-Friesian and Jersey, respectively, and 439 and $448 \mathrm{~kg}$ for high and low RFI, respectively. The RFI is the difference between amount of feed DM required for biological processes and estimated feed requirements based on a regression of feed DM against BW and daily $\mathrm{BW}$ gain. The midpoint in each vertical bar is the least squares means for the group; the error bars indicate the $95 \%$ confidence interval. 
ing stations. Briefly, the commercial GreenFeed system (C-Lock Inc., Rapid City, SD) for measuring $\mathrm{CH}_{4}$ production (Huhtanen et al., 2015; Hammond et al., 2016) was incorporated into a custom-built feed station (92 $\times 92 \times 81 \mathrm{~cm}^{3}$ ) with a sealed lid. Air was extracted at $45 \mathrm{~L} / \mathrm{s}$ using a fan, and the system integrated measurements of air flow and gas concentrations to allow direct measurement of $\mathrm{CH}_{4}$ fluxes during each animal visit to the feed station (Huhtanen et al., 2015). Each feed bin was supported on 2 load cells (C-Lock Inc.) and weights were recorded at 0.02 -s intervals to an accuracy of 0.1 $\mathrm{kg}$. Validation of bin accuracy during the experiment was based on weekly calibration with known weights and by checking whole-pen intake data against cumulative daily disappearance from each bin.

The 28 heifers in each cohort were randomly assigned to 1 of 2 pens, ensuring equal representation of each breed and RFI category in each pen $(n=14$ heifers/ pen in each cohort). Heifers were weighed thrice weekly. Heifers had free access to at least 3 feed stations in their pen. All feed was consumed from these feed stations, enabling daily intake for each animal to be calculated. Water was freely available. Heifers were offered unrestricted access to the same batch of dried alfalfa cubes as used in the original RFI measurement. Samples of alfalfa cubes were dried thrice weekly in triplicate at $95^{\circ} \mathrm{C}$ for $48 \mathrm{~h}$ to determine DM content (\%) and at $65^{\circ} \mathrm{C}$ for $72 \mathrm{~h}$ for nutritional analyses by neat infrared spectroscopy. Nutritional analysis indicated reasonable feed values (mean $\pm \mathrm{SD}$ ): $88.1 \pm 0.2 \% \mathrm{DM}$; $\mathrm{CP}, 20.6$ $\pm 0.30 \%$ DM; NDF, $36.2 \pm 0.80 \%$ DM; ADF, $30.6 \pm$ $0.91 \% \mathrm{DM}$; and fat, $1.6 \pm 0.0 \%$ DM. Feed disappearance/animal $(\mathrm{kg})$ was multiplied by the most recently measured feed DM percentage to determine individual animal daily DMI. Animals were in the pens for 32 $\mathrm{d}$ for cohort 1 and $25 \mathrm{~d}$ for cohort 2. The measurement period of the 2 cohorts differed in length due to the requirement to return the animals in cohort 2 to their farm of origin, but were deemed to be of sufficient length for intake and $\mathrm{CH}_{4}$ determination.

For each cohort, the first $7 \mathrm{~d}$ was treated as an adaptation period and excluded from the statistical analysis. The length of the subsequent measurement period was $25 \mathrm{~d}$ for cohort 1 (d 8 to 32 ) and $18 \mathrm{~d}$ for cohort 2 (d 8 to 25). Intake and $\mathrm{CH}_{4}$ data were downloaded from the feed stations and manually checked for accuracy. Poor reconciliation of data was uncommon and usually related to occasional failure of electronics, short visit times, or an animal bumping or moving the feed bins. Care was taken to ensure valid bases for data exclusion, and incorrect values were removed. Intake data for any animals with access to units that had temporary failure of electronics were removed for all affected days. Bin feed disappearance records with a start or end mass
$<-1 \mathrm{~kg}$ or $>150 \mathrm{~kg} /$ visit were removed, as the feed bin held $\sim 130 \mathrm{~kg}$ of alfalfa cubes. Any intakes less than $0 \mathrm{~kg}$ (due to data recorded while bins were being filled) were removed; $11 \%$ of intake data were excluded from analysis. Intake data were summed to and multiplied by the most recent DM percentage to provide daily DMI for each heifer. The mean of the daily DMI for each animal was used for further analyses. The $\mathrm{CH}_{4}$ data were removed when individual animal visits were $<1$ min and when there was equipment failure. The extraction fan failed for all days in 1 of the 7 feed stations; therefore, no $\mathrm{CH}_{4}$ data were available for this unit. Feed disappearance data were still collected and $\mathrm{CH}_{4}$ data were available from the other feed stations in that pen; $33 \%$ of methane data were excluded from analysis. Following implementation of the data exclusion criteria, the data set included 1,111 individual heifer daily DMI measures (an average of $20 \mathrm{~d} /$ heifer) and 6,110 measures of $\mathrm{CH}_{4}$ (an average of 109 per heifer for the duration of the measurement period) for the 56 animals.

Average $\mathrm{CH}_{4}$ for each animal was calculated from the arithmetic mean of all measurements for all days. Linear regression analyses were used to describe the relationship between BW and day of trial, with the slope equal to average daily BWg. The average BW for each animal for the trial was estimated as the predicted BW at the midpoint of the experimental period (d 20 for cohort 1 , and $\mathrm{d} 16.5$ for cohort 2: $\mathrm{BW}$ and $\mathrm{BWg}$ were $444(51.5) \mathrm{kg}$ and $1.2(0.31) \mathrm{kg} / \mathrm{d}$, respectively (mean with SD in parentheses). Methane yield (expressed as $\mathrm{g} / \mathrm{kg}$ of DMI) was calculated by dividing average $\mathrm{CH}_{4}$ production $(\mathrm{g} / \mathrm{d})$ by average DMI, and $\mathrm{CH}_{4} / \mathrm{kg}$ of $\mathrm{BWg}$ was calculated by dividing average $\mathrm{CH}_{4}$ production (g/d) by the average BWg: $\mathrm{CH}_{4} / \mathrm{d}, \mathrm{CH}_{4} / \mathrm{kg}$ of DMI, and $\mathrm{CH}_{4} / \mathrm{kg}$ of BWg were 255 (25.6), 21.7 (2.67), and 216 (52.2) g, respectively (mean, with SD in parentheses).

Dependent variables were analyzed with a linear model that included breed, RFI category, cohort, and the interaction of breed and RFI category as fixed effects, and heifer as the random effect. Statistical analyses were performed using $\mathrm{R}$ (version 3.3.3, $\mathrm{R}$ Core Team, 2017). Results are presented as least squares means and SE of the difference or $95 \%$ confidence intervals. Significance was declared at $P<0.05$.

Average RFI results for the $\mathrm{HF}$ and $\mathrm{J}$ breeds and the high and low RFI categories are presented in Figure 1, and $\mathrm{CH}_{4}, \mathrm{DMI}$, and BWg summary data are presented in Table 1. The experiment was not designed with sufficient statistical power to detect breed $\times$ RFI category interactions $(P>0.36)$; therefore, only breed or RFI differences are presented. We found no significant differences between RFI categories in BW or daily BWg $(P>0.25)$, but DMI and DMI $/ \mathrm{kg}$ of BW were 9.3 and $10.6 \%$ lower $(P<0.01)$ in low RFI heifers compared 
Table 1. Least squares means for groups representing 2 breeds and 2 predetermined residual feed intake (RFI) categories

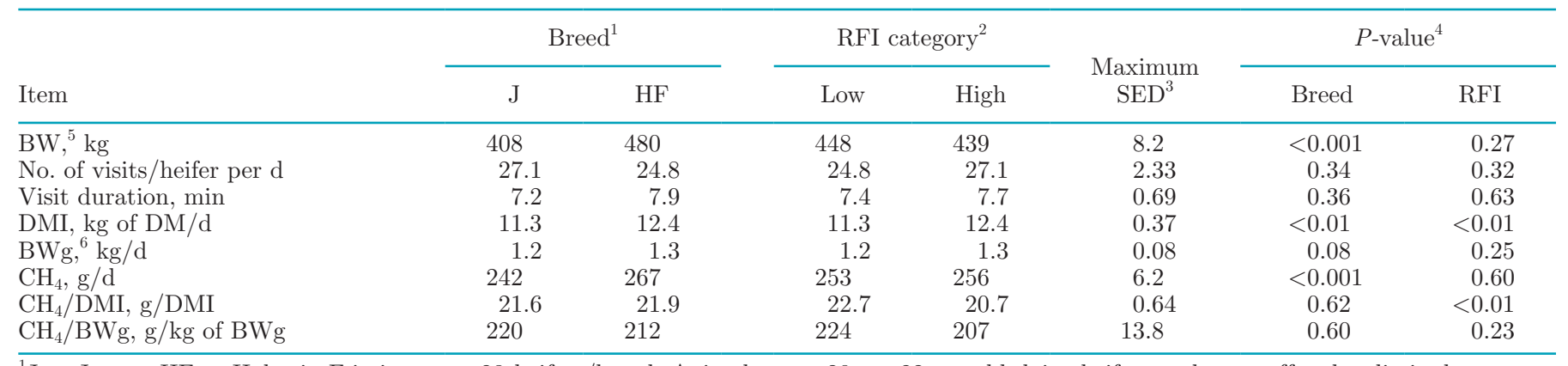

${ }^{1} \mathrm{~J}=$ Jersey; HF $=$ Holstein-Friesian; $\mathrm{n}=28$ heifers/breed. Animals were 20- to 22-mo-old dairy heifers and were offered unlimited access to dried alfalfa cubes.

${ }^{2}$ The RFI is the difference between the amount of feed ( $\mathrm{kg}$ of $\left.\mathrm{DM}\right)$ required for biological processes and estimated feed requirements based on a regression of feed against BW and BW gain. For this experiment, the top and bottom $10 \%$ of heifers were selected from an experiment in which 280 heifers (140 HF and $140 \mathrm{~J}$ ) were assessed for their RFI. Low RFI $=-2.1 \mathrm{~kg}$ of DMI $/ \mathrm{d}$ and high RFI $=+2.0 \mathrm{~kg}$ of DMI $/ \mathrm{d} ; \mathrm{n}=28 \mathrm{heifers}$ / RFI category.

${ }^{3}$ Standard error of the difference.

${ }^{4}$ Breed $\times$ RFI category interactions were not significant $(P>0.36)$; therefore, only breed or RFI differences are presented.

${ }^{5} \mathrm{BW}=$ average $\mathrm{BW}$ estimated as the predicted $\mathrm{BW}$ at the midpoint of the experiment.

${ }^{6} \mathrm{BWg}=$ average daily $\mathrm{BW}$ gain.

with their high RFI counterparts, confirming the accuracy of their designation to RFI category. On average, low RFI heifers ate $1.2 \mathrm{~kg} \mathrm{DM} / \mathrm{d}$ less $(P<0.01)$ than heifers in the high RFI category. This effect of RFI was anticipated and has been reported previously (Green et al., 2013). Consistent with our results, Waghorn et al. (2012) reported that the DMI difference between the top and bottom 10\% RFI heifers selected in a similar manner from a cohort of 1,052 heifers was $1.5 \mathrm{~kg}$ of $\mathrm{DM} / \mathrm{d}$.

Contrary to our hypothesis, no significant differences were observed between RFI categories on $\mathrm{CH}_{4}$ production $/ \mathrm{d}$ or $\mathrm{CH}_{4} / \mathrm{kg}$ of BWg. However, because of their similar $\mathrm{CH}_{4}$ production but lower DMI, low RFI heifers produced $2.0 \mathrm{~g}$ more $(P<0.01) \mathrm{CH}_{4} / \mathrm{kg}$ of DMI, or had a $9.7 \%$ greater $\mathrm{CH}_{4}$ yield than heifers in the high RFI category (Table 1). The lack of effect of RFI category on daily $\mathrm{CH}_{4}$ production was surprising but might indicate that a difference in ruminal digestive efficiency is one of the main reasons for the greater FCE in low RFI heifers. If the lower RFI was a result of greater ruminal feed digestibility, particularly NDF digestibility in a high forage diet, this would be expected to increase $\mathrm{CH}_{4}$ yield (g/kg of DMI; Ramin and Huhtanen, 2013; Moate et al., 2016). Our new hypothesis is that greater $\mathrm{CH}_{4}$ yield $/ \mathrm{kg}$ of DMI in low RFI heifers is a result of greater ruminal digestion of DM and NDF; this is supported by previous work investigating phenotypic differences between animals selected for low and high RFI. For example, cows selected for low RFI performed fewer and more intense rumination bouts. This would be expected to increase the physical breakdown of forage (Gregorini et al., 2015), which was supported by the fecal particle size distribution measured in their study: relative to the high RFI cows, low RFI cows excreted feces with $30 \%$ fewer large particles, indicating a greater level of ruminal digestion of the forage (Clauss et al., 2010) and the potential for greater $\mathrm{CH}_{4}$ yield. Furthermore, Rius et al. (2012) reported that low RFI dairy heifers had a greater apparent total-tract N digestibility and a tendency toward greater DM and OM digestibility. Nkrumah et al. (2006) also reported a tendency toward greater DM digestibility with greater efficiency in beef steers and numerically higher NDF and ADF digestibility. These data are consistent with a greater ruminal digestion of NDF and, as a result, increased $\mathrm{CH}_{4} / \mathrm{kg}$ of DMI in low RFI animals on a high forage diet. Therefore, although selecting dairy heifers for low RFI increases FCE and reduces the inputs per kilogram of BWg (Waghorn et al., 2012) and milk (Macdonald et al., 2014), it is unlikely to reduce total daily $\mathrm{CH}_{4}$ production because the animals produce more $\mathrm{CH}_{4} / \mathrm{kg}$ of DMI.

Previously reported effects of RFI on enteric $\mathrm{CH}_{4}$ production in cattle are limited to beef cattle. Although most studies report a positive relationship between RFI and both DMI and $\mathrm{CH}_{4}$ production (Nkrumah et al., 2006; Hegarty et al., 2007; Fitzsimons et al., 2013), the effect of RFI on $\mathrm{CH}_{4}$ is not consistent across all studies (McDonnell et al., 2016). The reason for the inconsistent effect of RFI on $\mathrm{CH}_{4}$ production is not known, but it might relate to differences in diet. Both Nkrumah et al. (2006) and Hegarty et al. (2007) offered growing beef steers a diet of predominantly cereal grains compared with the dried alfalfa cubes offered in our experiment. These dietary differences would result in very different 
rumen fermentation patterns and expected $\mathrm{CH}_{4}$ yields/ $\mathrm{kg}$ of DMI (Ramin and Huhtanen, 2013; Moate et al., 2017). Fitzsimons et al. (2013) offered unrestricted access to pasture silage, a forage with no starch, similar to the diet used in our experiment in terms of rumen fermentation products. However, they also reported a reduction in $\mathrm{CH}_{4}$ production in low RFI steers. In comparison, McDonnell et al. (2016) offered pasture silage, fresh pasture, or a TMR and reported no effect of RFI on $\mathrm{CH}_{4}$ production and an increase in $\mathrm{CH}_{4}$ yield in low RFI animals, similar to our results. Sex may be another source of difference, with many of the animals evaluated in the beef studies being male castrates. These may have a different physiology underpinning RFI compared with dairy heifers. Age and production stage may also be a factor in the inconsistency of results between studies. Age and production stage have been reported to affect RFI in dairy cattle. For example, Macdonald et al. (2014) reported that animals identified as being $21 \%$ different in RFI as calves were only $3 \%$ different in RFI as lactating cows. Although we cannot determine with any certainty the reason for the inconsistency in reported effects of RFI on $\mathrm{CH}_{4}$ yield and production, our results do not support a positive effect of RFI on daily $\mathrm{CH}_{4}$ production by dairy heifers approaching $2 \mathrm{yr}$ of age when consuming dry alfalfa cubes.

Dairy breed affected $(P<0.01)$ BW, DMI, and $\mathrm{CH}_{4}$ yield. The HF heifers were approximately $70 \mathrm{~kg}$ heavier than their $\mathrm{J}$ counterparts and there was a trend $(P<$ $0.10)$ for HF to have a greater average daily BWg. The trend for a BWg difference is consistent with HF heifers consuming $1.1 \mathrm{~kg}$ more $\mathrm{DM} / \mathrm{d}(P<0.01)$ than $\mathrm{J}$ heifers. Because of their lower DMI, J heifers produced about $25 \mathrm{~g}$ less $\mathrm{CH}_{4} / \mathrm{d}(P<0.01$; approximately $9.3 \%)$ than the HF heifers. However, breed did not affect $\mathrm{CH}_{4} / \mathrm{kg}$ of DMI or $\mathrm{CH}_{4} / \mathrm{kg}$ of BWg. The lack of breed effect on $\mathrm{CH}_{4}$ yield in our study is consistent with previous reports. In their review, Goddard and Grainger (2003) concluded that, despite reported differences in FCE and metabolic heat production, no difference existed in $\mathrm{CH}_{4}$ yield $(\mathrm{g} /$ $\mathrm{kg}$ of DMI) between HF and J breeds. A breed effect on DMI has been previously reported (Goddard and Grainger, 2003; Prendiville et al., 2010; Beecher et al., 2014; Spaans et al., 2018); therefore, we hypothesized that the relatively larger gastrointestinal tract of the $\mathrm{J}$ (Beecher et al., 2014) and the greater FCE of the J breed (L'Huillier et al., 1988; Prendiville et al., 2009; Spaans et al., 2018) would result in a lower $\mathrm{CH}_{4} / \mathrm{kg}$ of DMI. Our experimental results do not support this. In fact, the RFI results indicate that, if anything, J heifers should have produced more $\mathrm{CH}_{4} / \mathrm{kg}$ of DMI if the reason for their reported $\mathrm{FCE}$ originated from ruminal digestion. The lack of effect of breed on $\mathrm{CH}_{4} / \mathrm{kg}$ of DMI suggests that improvements in ruminal digestibility do not explain the reported improvement in FCE in J animals. Further research is required to understand the mechanisms supporting the greater FCE in the J breed; however, our data indicate that dairy breed itself does not affect $\mathrm{CH}_{4} / \mathrm{kg}$ of DMI, and any difference in daily $\mathrm{CH}_{4}$ production is associated with differences in DMI.

In conclusion, consistent with previous beef cattle experiments, considerable variation occurs in RFI in growing dairy heifers. Even with a large difference in DMI in divergent animals, RFI categorization did not affect daily $\mathrm{CH}_{4}$ production $(\mathrm{g} / \mathrm{d})$. As a result, $\mathrm{CH}_{4}$ yield ( $\mathrm{g} / \mathrm{kg}$ of DMI) was greater in low RFI animals. We hypothesize that this is because of increased ruminal NDF digestibility. Jersey heifers had a lower DMI than their heavier HF counterparts and, therefore, produced less $\mathrm{CH}_{4} / \mathrm{d}$; however, there was no effect of breed on $\mathrm{CH}_{4}$ yield (i.e., $\mathrm{g} \mathrm{CH}_{4} / \mathrm{kg}$ of DMI).

\section{ACKNOWLEDGMENTS}

The authors acknowledge all the help afforded them by Lye Farm staff (Hamilton, New Zealand) and the technical support of Olivia Jordan and Mark Bryant (DairyNZ, New Zealand). This research was funded by the New Zealand Government to support the objectives of the Livestock Research Group of the Global Research Alliance on Agricultural Greenhouse Gases (https://globalresearchalliance.org/).

\section{REFERENCES}

Beecher, M., F. Buckley, S. M. Waters, T. M. Boland, D. EnriquezHidalgo, M. H. Deighton, M. O'Donovan, and E. Lewis. 2014. Gastrointestinal tract size, total-tract digestibility, and rumen microflora in different dairy cow genotypes. J. Dairy Sci. 97:3906-3917. https://doi.org/10.3168/jds.2013-7708.

Clauss, M., I. D. Hume, and J. Hummel. 2010. Evolutionary adaptations of ruminants and their potential relevance for modern production systems. Animal 4:979-992. https://doi.org/10.1017/ S1751731110000388.

Davis, S. R., K. A. Macdonald, G. C. Waghorn, and R. J. Spelman. 2014. Residual feed intake of lactating Holstein-Friesian cows predicted from high-density genotypes and phenotyping of growing heifers. J. Dairy Sci. 97. https://doi.org/10.3168/jds.2013-7205.

Fitzsimons, C., D. A. Kenny, M. H. Deighton, A. G. Fahey, and M. McGee. 2013. Methane emissions, body composition, and rumen fermentation traits of beef heifers differing in residual feed intake. J. Anim. Sci. 91:5789-5800. https://doi.org/10.2527/jas.2013 $-6956$.

Garnsworthy, P. C., J. Craigon, J. H. Hernandez-Medrano, and N. Saunders. 2012. On-farm methane measurements during milking correlate with total methane production by individual dairy cows. J. Dairy Sci. 95:3166-3180. https://doi.org/10.3168/jds.2011-4605.

Goddard, C., and M. E. Grainger. 2003. A review of the effects of dairy breed on feed conversion efficiency-An opportunity lost? Anim. Prod. Aust. 25:77-80.

Green, T. C., J. G. Jago, K. A. Macdonald, and G. C. Waghorn. 2013. Relationships between residual feed intake, average daily gain, and feeding behavior in growing dairy heifers. J. Dairy Sci. 96:30983107. https://doi.org/10.3168/jds.2012-6087. 
Gregorini, P., G. C. Waghorn, B. Kuhn-Sherlock, A. J. Romera, and K. A. Macdonald. 2015. Short communication: Grazing pattern of dairy cows that were selected for divergent residual feed intake as calves. J. Dairy Sci. 98:6486-6491. https://doi.org/10.3168/jds .2015-9614.

Hammond, K. J., G. C. Waghorn, and R. S. Hegarty. 2016. The GreenFeed system for measurement of enteric methane emission from cattle. Anim. Prod. Sci. 56:181-189. https://doi.org/10.1071/ AN15631.

Hegarty, R. S., J. P. Goopy, R. M. Herd, and B. McCorkell. 2007. Cattle selected for lower residual feed intake have reduced daily methane production. J. Anim. Sci. 85:1479-1486. https://doi.org/ 10.2527/jas.2006-236.

Huhtanen, P., E. H. Cabezas-Garcia, S. Utsumi, and S. Zimmerman. 2015. Comparison of methods to determine methane emissions from dairy cows in farm conditions. J. Dairy Sci. 98:3394-3409. https://doi.org/10.3168/jds.2014-9118.

Knapp, J. R., G. L. Laur, P. A. Vadas, W. P. Weiss, and J. M. Tricarico. 2014. Invited review: Enteric methane in dairy cattle production: Quantifying the opportunities and impact of reducing emissions. J. Dairy Sci. 97:3231-3261. https://doi.org/10.3168/jds 2013-7234.

L'Huillier, P. J., C. R. Parr, and A. M. Bryant. 1988. Comparative performance and energy metabolism of Jerseys and Friesians in early-mid lactation. Proc. N.Z. Soc. Anim. Prod. 48:231-235.

Macdonald, K. A., J. E. Pryce, R. J. Spelman, S. R. Davis, W. J. Wales, G. C. Waghorn, Y. J. Williams, L. C. Marett, and B. J. Hayes. 2014. Holstein-Friesian calves selected for divergence in residual feed intake during growth exhibited significant but reduced residual feed intake divergence in their first lactation. J. Dairy Sci. 97:1427-1435. https://doi.org/10.3168/jds.2013-7227.

McDonnell, R. P., K. J. Hart, T. M. Boland, A. K. Kelly, M. McGee, and D. A. Kenny. 2016. Effect of divergence in phenotypic residual feed intake on methane emissions, ruminal fermentation, and apparent whole-tract digestibility of beef heifers across three contrasting diets. J. Anim. Sci. 94:1179-1193. https://doi.org/10 $.2527 /$ jas.2015-0080.

Moate, P. J., M. H. Deighton, S. R. O. Williams, J. E. Pryce, B. J. Hayes, J. L. Jacobs, R. J. Eckard, M. C. Hannah, and W. J. Wales. 2016. Reducing the carbon footprint of Australian milk production by mitigation of enteric methane emissions. Anim. Prod. Sci. 56:1017-1034. https://doi.org/10.1071/AN15222.

Moate, P. J., S. R. O. Williams, J. L. Jacobs, M. C. Hannah, K. A Beauchemin, R. J. Eckard, and W. J. Wales. 2017. Wheat is more potent than corn or barley for dietary mitigation of enteric methane emissions from dairy cows. J. Dairy Sci. 100:7139-7153. https: //doi.org/10.3168/jds.2016-12482.

Nkrumah, J. D., E. K. Okine, G. W. Mathison, K. Schmid, C. Li, J. A. Basarab, M. A. Price, Z. Wang, and S. S. Moore. 2006. Relation- ships of feedlot feed efficiency, performance, and feeding behavior with metabolic rate, methane production, and energy partitioning in beef cattle. J. Anim. Sci. 84:145-153.

Pacheco, D., G. Waghorn, and P. H. Janssen. 2014. Decreasing methane emissions from ruminants grazing forages: a fit with productive and financial realities? Anim. Prod. Sci. 54:1141-1154.

Potts, S. B., J. P. Boerman, A. L. Lock, M. S. Allen, and M. J. VandeHaar. 2015. Residual feed intake is repeatable for lactating Holstein dairy cows fed high and low starch diets. J. Dairy Sci. 98:4735-4747. https://doi.org/10.3168/jds.2014-9019.

Prendiville, R., K. M. Pierce, and F. Buckley. 2009. An evaluation of production efficiencies among lactating Holstein-Friesian, Jersey, and Jersey x Holstein-Friesian cows at pasture. J. Dairy Sci. 92:6176-6185. https://doi.org/10.3168/jds.2009-2292.

Prendiville, R., K. M. Pierce, and F. Buckley. 2010. A comparison between Holstein-Friesian and Jersey dairy cows and their F1 cross with regard to milk yield, somatic cell score, mastitis, and milking characteristics under grazing conditions. J. Dairy Sci. 93:27412750. https://doi.org/10.3168/jds.2009-2791.

Pryce, J. E., J. A. Arias, P. J. Bowman, S. R. Davis, K. A. MacDonald, G. C. Waghorn, W. J. Wales, Y. J. Williams, R. J. Spelman, and B. J. Hayes. 2012. Accuracy of genomic predictions of residual feed intake and 250-day body weight in growing heifers using 625,000 single nucleotide polymorphism markers. J. Dairy Sci. 95:2108-2119. https://doi.org/10.3168/jds.2011-4628.

R Core Team. 2017. R: A language and environment for statistical computing. R Foundation for Statistical Computing, Vienna, Austria. http://www.R-project.org/.

Ramin, M., and P. Huhtanen. 2013. Development of equations for predicting methane emissions from ruminants. J. Dairy Sci. 96:24762493. https://doi.org/10.3168/jds.2012-6095.

Rius, A. G., S. Kittelmann, K. A. Macdonald, G. C. Waghorn, P. H. Janssen, and E. Sikkema. 2012. Nitrogen metabolism and rumen microbial enumeration in lactating cows with divergent residual feed intake fed high-digestibility pasture. J. Dairy Sci. 95:50245034. https://doi.org/10.3168/jds.2012-5392.

Spaans, O. K., K. A. Macdonald, J. A. S. Lancaster, A. M. Bryant, and J. R. Roche. 2018. Dairy cow breed interacts with stocking rate in temperate pasture-based dairy production systems. J. Dairy Sci. 101:4690-4702

van Soest, P. J. 1994. Nutritional Ecology of the Ruminant. 2nd ed. Cornell University Press, Ithaca, NY.

Waghorn, G. C., K. A. Macdonald, Y. Williams, S. R. Davis, and R. J. Spelman. 2012. Measuring residual feed intake in dairy heifers fed an alfalfa (Medicago sativa) cube diet. J. Dairy Sci. 95:1462-1471. https://doi.org/10.3168/jds.2011-4670.

Zimmerman, S., J. Roche, and P. Zimmerman. 2015. Aerodynamic design of a TMR feed bin to measure gaseous emissions from cattle. J. Dairy Sci. 98(Suppl. 2):599. (Abstr.) 